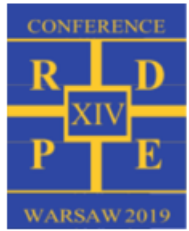

\title{
Evaluation of electricity generation subsystem of Power-to-Gas- to-Power unit using gas expander and heat recovery steam generator
}

\author{
Daria $\mathrm{K}_{\text {atl }} \mathrm{a}^{1,}{ }^{*}$, Eukasz B artel $\mathrm{a}^{2}$, and Anna Skorek-0 sikowska ${ }^{3}$ \\ 1Silesian University of Technology, A kademicka 2A 44-100 Gliwice, daria.katla@ polsl.pl, Poland \\ 2Silesian University of Technology, A kademicka 2A 44-100 Gliwice, lukasz.bartela@ polsl.pl, Poland \\ ${ }^{3}$ Silesian University of Technology, A kademicka 2A 44-100 Gliwice, anna.skorek-osikowska@ polsl.pl, Poland
}

\begin{abstract}
In the last years, the European energy policy has required to increase the share of renewable energy sources in the national energy systems. It is important to diversify the energy system not to bring about a global crisis resulting from the fundamental lack of electricity. U nfortunately renewable sources are unstable and generate several problems during integration with the power grid. The solution is to store additional energy produced from renewable sources. In this way, energy can be used when there is a need. The paper discusses the study of the Power-to-Gas-to-Power installation using electrolysis and methanation processes at the energy storage stage and gas expanders during energy discharges. In addition, a part of the Heat Recovery Steam Generation installation has been implemented. The purpose of the work was to determine the impact of a given Heat Recovery Steam Generation installation on the efficiency of the entire installation and flue gas temperature at the outlet from Heat Recovery Steam Generator.
\end{abstract}

\section{Introduction}

The demand for energy is constantly growing. Globally the energy sector mainly focuses on the exploitation of fossil fuels for energy production. Fossil resources are exhaustible, and the cost of their exploitation is constantly increasing, as is the difficulty of their extraction. Combustion of fossil fuels also results in the emission of various harmful substances such as nitrogen, sulfur or carbon oxides into the environment, which strongly affect the increase of the greenhouse effect. Energy policy draws attention to improving energy efficiency, increasing the security of fuels and energy supply, diversifying the structure of electricity generation through the introduction of nuclear energy, developing the use of renewable energy sources (RES), developing competitive fuel and energy markets and reducing the impact of energy on the environment.

Turning to alternative energy sources is inevitable. Their unquestionable advantage over non-renewable sources is their unlimited access. A mong other things, water, tidal waves, and sea currents, as well as temperature differences in the deep sea, are used. Wind energy put the wind turbine in the motion. Solar energy is used both for the production of electricity in photovoltaic cells and for the production of heat in solar collectors. A nother example is geothermal energy used, among others, in heat pumps. Although biomass is considered in many countries in the world as a renewable source, its energetic use is associated with the emission of harmful substances. For this reason, currently, in accordance with the law of the European Union (which is courtially questioned), biomass is not a renewable source. Energy from coal, oil and natural gas still prevails, but in recent years there has been an increase in the share of different energy sources in the global energy mix. There are a number of investments in the nuclear energy sector but also in renewable energy sources. Among others, the member states of the European Union have committed to increasing the share of energy from renewable sources to $30 \%$ by 2030 [1-3]. Such legal files as [4,5], are focused not only on increasing the use of renewable energy sources but also pay attention to reducing pollutant emissions and increasing energy security, understood as the diversification of fuels used for energy production. The advantages of renewable energy sources include, universality, free-flow and reduction of pollutant emissions. However, with the use of renewable energy sources installations, several unfavourable aspects are associated, such as production unpredictability, lack of continuity of energy supply or terrain conditions.

The legal regulations established by the EU for the $M$ ember States, support the production of energy from RES and impose its priority in grid connection. Sometimes this is problematic because, on days where there is a lot of energy produced from renewable energy, conventional producers are rejected. Which is another problem related to the necessity of discontinuing conventional blocks and generating huge costs. A complication is a fact that the energy produced by the RES is intermittent and dependent on particular conditions. The wind farm capacity rate for European countries is around 20-40\%, which depends, among others on area configuration. Also, electricity produced from renewable sources cannot always provide 
an immediate reaction to demand, because these sources do not generate energy on a regular basis. The increase of this decentralized production means more problems with the stability of grid operation. But investing in renewable energy sources and hence, wind energy will continue to take place [6]. Therefore, a compromise should be found between increasing the share of renewable energy sources in the global energy mix and the possibility of their implementation in the national power systems without major losses. The answer could be storing of surplus renewable energy without rejecting conventional technologies. Considering the energy storage systems, it is possible to match the production potential with the current demand.

\section{Power-to-Gas-to-Power process chain description}

Power-to-Gas (P-t-G) technology is a technology of energy storage, so it is a solution that could implement energy from renewable sources and released it to the grid during summit hours [7,8]. The storage of electricity requires its conversion into a form that is easier to accumulate. The conversion of electric energy into chemical energy occurs during the process of electrolysis of water, which products are hydrogen and oxygen in the gas form [9]. Hydrogen produced in the electrolysis process can be stored and then used in the production of heat as well as electricity (Fig. 1). Hydrogen, due to its properties, is suitable as fuel. It has the highest Lower Heating Value. As conventional fuel, it is mainly used in rockets. The automotive industry is dominated by engines based on fuel cells [10].

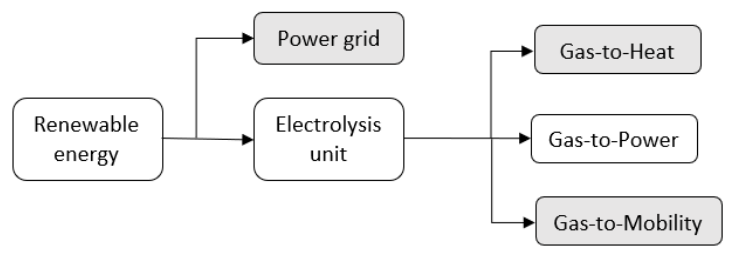

Fig. 1.Simplified block diagram of Power-to-Gas technology

Unfortunately, there are many problems related to the production, buffering, transport and use of pure hydrogen. For example, it requires the use of expensive and still imperfect technology for the installation of fuel cells. The hydrogen can be also synthesized to different types of hydrocarbon fuels. The alternative is to introduce a methanation installation into the process chain of Power-to-Gas installation (Fig. 2) to produce Synthetic Natural Gas (SNG) from hydrogen and carbon monoxide or carbon dioxide in the Sabatier process $[11,12]$. The great advantage of methane synthesis from hydrogen is that it can be introduced into the gas distribution system without any restrictions and also the storage in pressurized tanks is less problematic [13-15]. Synthetic methane can be actually used in the same infrastructure as commercial natural gas. It means that this technology requires less expensive expenditures of exploitation than hydrogen technology, where conditions of combustion or use in fuel cells cannot be defined as reliable and known technology [16,17]. Generated SNG can be used both to heat as well as to electricity production. The most common method to produce power from Synthetic Natural Gas are gas turbine generators [18].

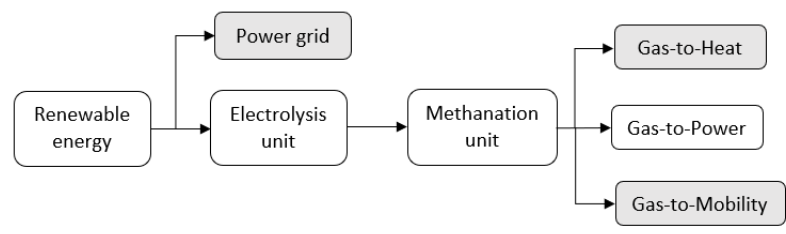

Fig.2.Simplified block diagram of Power-to-Gas technology with methanation unit

\section{Description of the mathematical model of a considered energy storage system}

Power-to-Gas-to-Power installation with methanation unit was a subject of analysis, assuming the use of standard gas expanders. The aim was to determine the thermodynamic efficiency of these systems.

It was assumed that the surplus renewable energy produced during the night valleys is supplied to the electrolyzer. The hydrogen then supplies the methanation unit in the appropriate cycles. The SNG produced in this process can be stored without restrictions in an existing gas network or stored and used during increased demand for energy production. Renewable energy is provided to the electrolyzer unit and the products of the reaction are hydrogen and oxygen. Generated gases are buffered. Hydrogen is introduced to the methanation unit and the product of this process is SNG. Synthetic methane combustion takes place in the combustion chamber in an atmosphere of oxygen and recirculated carbon dioxide. The combustion is stoichiometric and there is no oxygen behind the combustion chamber. Thanks to the oxycombustion process, we can separate carbon dioxide through condensation, thanks to which the installation is emission-free, this carbon dioxide is recirculated to the combustion chamber ensuring proper conditions for natural gas combustion. Non-recirculated carbon dioxide can be also stored and further treated as a commercial product, used in broadly understood chemistry. Exhaust gases are directed to the gas expander system, where electricity is generated. Behind the expander, there is a heat exchanger that cools the hot exhaust gases and dissipates the heat. From the gases leaving the heat exchanger, carbon dioxide is separated by condensation of water vapor. The condensed water is stored to be used in the electrolysis process and the remaining part of the separated carbon dioxide is buffered for and used in the methanation unit for the production of SNG.

A big disadvantage in terms of efficiency of this system is a very high heat flux, which is dispersed in the environment by cooling the exhaust gases leaving the expander to separate the carbon dioxide from the water. The exhaust gases leaving the gas expander system have a high temperature, about $500{ }^{\circ} \mathrm{C}$, while the outlet 
temperature of the heat exchanger is $30^{\circ} \mathrm{C}$. In this way, a very large amount of heat is not used. To increase the efficiency of the system, it was proposed to use high temperature heat for the production of electricity. Therefore, six systems with heat recovery steam generator (HRSG) system were considered. In Figure 3 a conceptual scheme of such a model is presented.

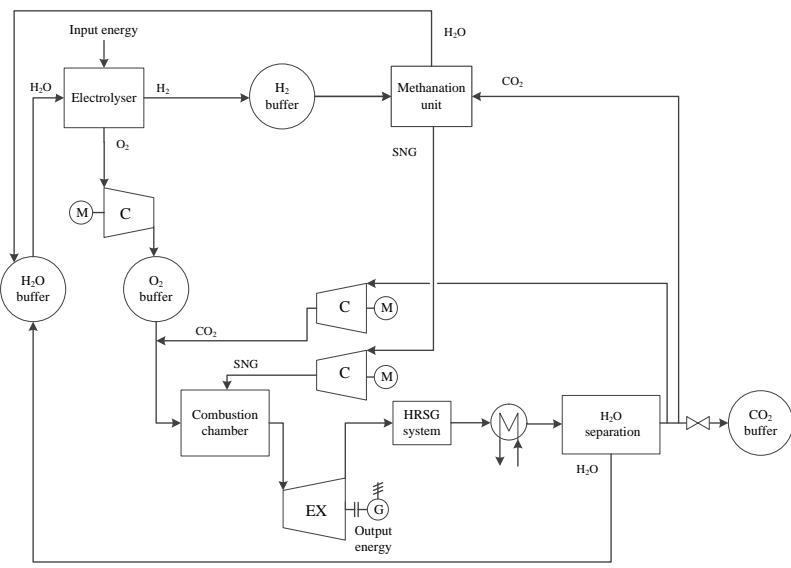

Fig.3.Simplified diagram of the considered Power-to-Gas-toPower case with HRSG system

\subsection{Energy production system}

Two possible configurations of the Gas-to-Power system have been taken into account in simulations, without and with HRSG system. The second configuration differs from the first with one element, which is the heat recovery steam generator (HRSG) system after the gas expander. The HRSG is a set of heat exchangers that include economizers, evaporators, and superheaters, which recover heat from the hot exhaust gases. Water is the working fluid and during this process, steam is generated. The steam is used to drive the steam turbine, so in this configuration, there is an additional energy generation. Six cases of HRSG systems were examined in this work. The impact of various constructions of the HRSG was analysed. The results were compared to the results obtained for the case without the HRSG system.

Before the simulation of the energy discharge process, a model of the methanation process in the Aspen Plus software was prepared. The composition of the obtained gas was implemented for further calculations (Tab 1).

Table 1.SNG composition accepted for further calculations

\begin{tabular}{|c|c|}
\hline Component & Mole fraction \\
\hline $\mathrm{H}_{2}$ & 0.037076 \\
\hline $\mathrm{CO}_{2}$ & 0.009061 \\
\hline $\mathrm{CH}_{4}$ & 0.945649 \\
\hline $\mathrm{H}_{2} \mathrm{O}$ & 0.008212 \\
\hline $\mathrm{CO}$ & $1.63 \cdot 10^{-6}$ \\
\hline
\end{tabular}

In Table 2, all assumptions used to model the cases using the Gate Cycle software were summarized. Variables that determine the results of the analysis are the gas temperature at the outlet of the combustion chamber and gas pressure at the outlet of the expander. The rest of the assumptions are constant for all calculations.

Table 2.Main assumptions for the energy production analysis

\begin{tabular}{|c|c|c|}
\hline Description & Value & Unit \\
\hline $\begin{array}{c}\text { Combustion chamber } \\
\text { outlet temperature }\end{array}$ & $800,900,1000$ & ${ }^{\circ} \mathrm{C}$ \\
\hline $\begin{array}{c}\text { Combustion chamber } \mathrm{O}_{2} \\
\text { and } \mathrm{CO}_{2} \text { inlet pressure }\end{array}$ & 3 & $\mathrm{MPa}$ \\
\hline $\begin{array}{c}\text { Combustion chamber } \\
\text { SNG inlet pressure }\end{array}$ & 4.5 & $\mathrm{MPa}$ \\
\hline $\begin{array}{c}\text { Gas expander outlet } \\
\text { pressure }\end{array}$ & $100-500$ & $\mathrm{kPa}$ \\
\hline $\begin{array}{c}\text { Heat exchanger water inlet } \\
\text { temperature }\end{array}$ & 15 & ${ }^{\circ} \mathrm{C}$ \\
\hline $\begin{array}{c}\text { Heat exchanger gas outlet } \\
\text { temperature }\end{array}$ & 30 & ${ }^{\circ} \mathrm{C}$ \\
\hline Compressor efficiency & 88 & $\%$ \\
\hline Gas expander efficiency & 90 & $\%$ \\
\hline Condenser outlet pressure & 10 & $\mathrm{kPa}$ \\
\hline $\begin{array}{c}\text { Lower Heating Value of } \\
\text { SNG }\end{array}$ & 48.66 & $\mathrm{MJ} / \mathrm{kg}$ \\
\hline
\end{tabular}

Six cases of HRSG systems were considered:

- $\quad$ HRSG1 - 1 pressure HRSG with steam extraction for deaerator,

- HRSG2 - 1 pressure HRSG with integral deaerator,

- $\quad$ HRSG3 - 2 pressure HRSG,

- HRSG4 - 2 pressure HRSG with reheat,

- HRSG5 - 3 pressure HRSG with reheat,

- HRSG6 - 3 pressure HRSG with reheat.

In general, the structure of each stage of the recovery boiler consists of an economizer (EC), an evaporator (EV) and a superheater (SHT), optionally a reheater (RH). Exhaust gases exiting the gas expander system (EX) are directed to the system of three heat exchangers: economizer, evaporator, and superheater. The economizer heats the water, which is then directed to the evaporator, the steam leaving the evaporator is overheated in superheater and directed to a steam turbine with steam bleed to deaerator (except for HRSG2 case where deaerator is fed with steam generated by the lowpressure evaporator of HRSG). Behind the turbine, there is a condenser, and the condensate also fed the deareator. The water pump closes the circuit by supplying the economizer. Each of them is presented in the Figure 4. 


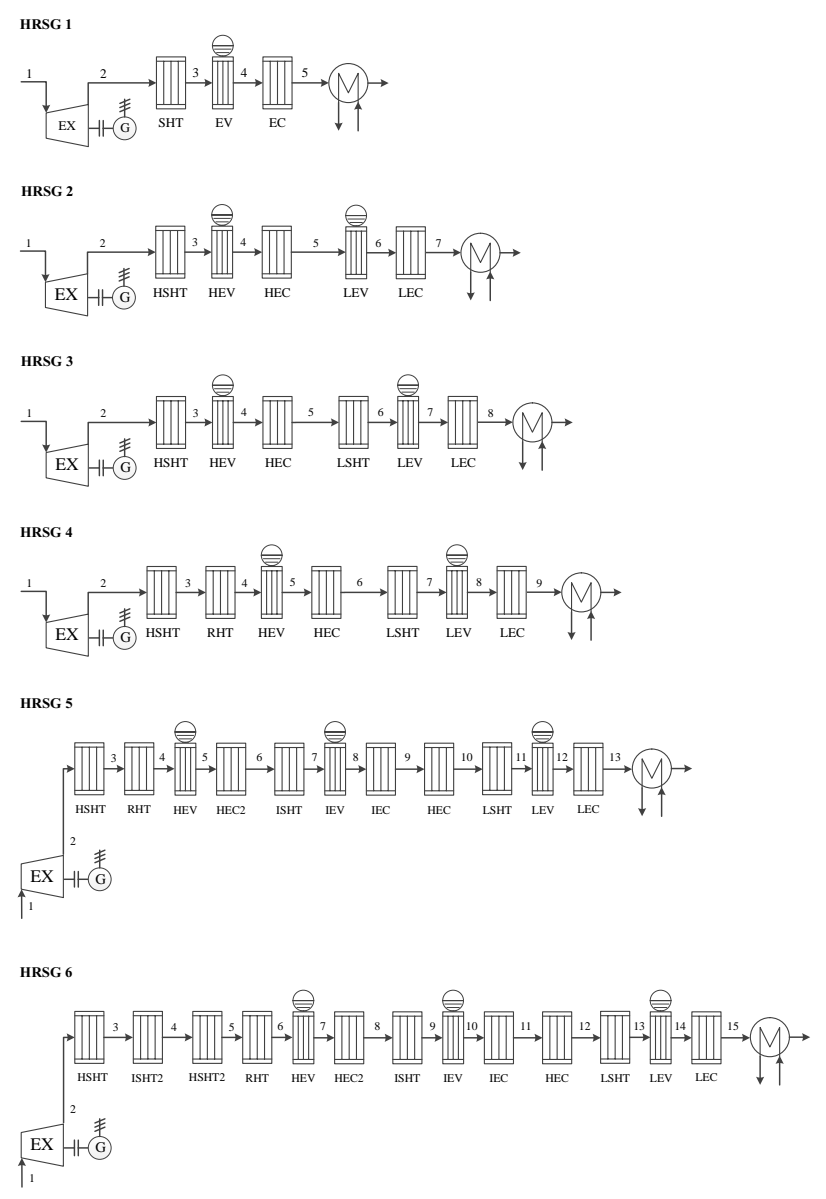

Fig.4.Graphic representation of all considered HRSG cases

Table 3 presents all the assumptions needed to perform the simulation of each system work, required by the Gate Cycle software. For each of the analyzed cases, the same assumptions were adopted for individual elements of the system. The inlet stream to the gas expander is compatible as from the model without the HRSG system.

Table 3.Main assumptions for the energy production analysis for cases with HRSG installation

\begin{tabular}{|c|c|c|}
\hline Description & Value & Unit \\
\hline Gas expander inlet temperature & 1000 & ${ }^{\circ} \mathrm{C}$ \\
\hline Gas expander inlet pressure & 3 & $\mathrm{MPa}$ \\
\hline Gas expander isentropic efficiency & 90 & $\%$ \\
\hline $\begin{array}{c}\text { High and intermediate-pressure } \\
\text { economizer exit subcooling }\end{array}$ & 3 & ${ }^{\circ} \mathrm{C}$ \\
\hline $\begin{array}{c}\text { Low-pressure economizer } \\
\text { effectiveness }\end{array}$ & 50 & $\%$ \\
\hline Evaporator pinch delta temperature & 8 & ${ }^{\circ} \mathrm{C}$ \\
\hline Superheater approach temperature & 30 & ${ }^{\circ} \mathrm{C}$ \\
\hline Heat exchangers' pressure loss & 1 & $\%$ \\
\hline Steam turbine isentropic efficiency & 90 & $\%$ \\
\hline Steam turbine generator efficiency & 98 & $\%$ \\
\hline Condenser desired pressure & 5 & $\mathrm{kPa}$ \\
\hline $\begin{array}{c}\text { Condenser fixed cooling water } \\
\text { temperature rise }\end{array}$ & 10 & ${ }^{\circ} \mathrm{C}$ \\
\hline Pump isentropic efficiency & 85 & $\%$ \\
\hline
\end{tabular}

\section{Results}

In order to compare all cases, the definition of energy storage efficiency has been introduced. Electrical energy obtained from the gas expander system is reduced by the work of the $\mathrm{CO}_{2}$ compressor and the work of a pump (if exists). The input effort is defined as the power of the hydrogen generator. Derived dependencies are true only when the charging time is the same as the discharging time of the unit. The energy storage efficiency is defined by the following equation:

$$
\eta_{E S}=\frac{N_{e l_{E X}}+N_{e l_{S T}}-N_{e l}-N_{e l P}}{N_{e l_{H G}}},
$$

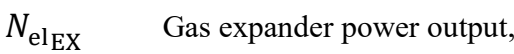

$N_{\text {el }}$ Steam turbine power output,

$N_{\text {el }} \quad$ Compressors power input,

$N_{\text {el }} \quad$ Pumps power input,

$N_{\text {el }}$ In Inut power of hydrogen generators.

Analysis of the system without HRSG in the Gate Cycle program was performed. The calculations were made for three temperatures behind the combustion chamber: 800 ${ }^{\circ} \mathrm{C}, 900{ }^{\circ} \mathrm{C}$, and $1000{ }^{\circ} \mathrm{C}$. The expander outlet pressure was changed from 100 to $500 \mathrm{kPa}$ with a step of $10 \mathrm{kPa}$. The results are presented in Figure 5. The output power of the system is expressed as the difference of the gas expander power output and the $\mathrm{CO}_{2}$ compressor power input. The highest output power occurs for a combustion temperature of $1000{ }^{\circ} \mathrm{C}$ and expander outlet equal to $100 \mathrm{kPa}$. Data from this configuration have been implemented for further analysis.

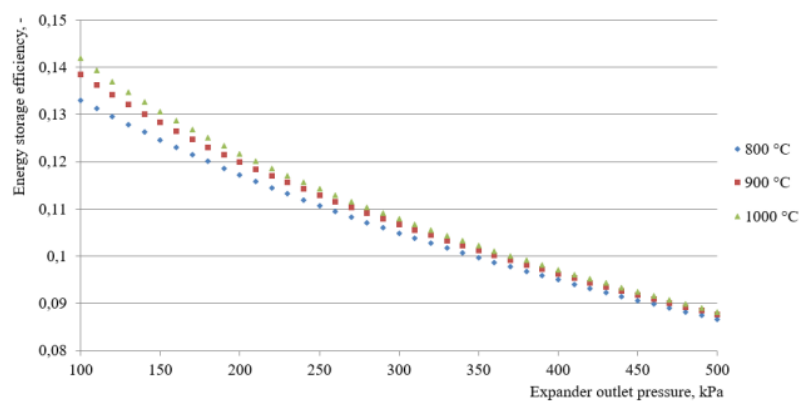

Fig.5.Dependence of gas expander power output as a function of expander outl et pressure for different start-up temperatures of the process

Then, the data was implemented to the models of HRSG systems in order to estimate, in which model the temperature at the outlet of the recovery boiler would be the lowest. The lowest temperature was calculated in the third case of the HRSG system. This is the most beneficial case from the point of view of the heat exchanger located before the $\mathrm{H}_{2} \mathrm{O}$ separator because the heat it receives is dissipated.

Table 4 presents data from all models that provide the generated power taking into account the needs of the systems. The highest efficiency is achieved in the fifth case of the models with the HRSG system. 
Table 4. The results of performance for all considered cases

\begin{tabular}{|c|c|c|c|}
\hline \multicolumn{2}{|c|}{ Case } & $T,{ }^{\circ} \mathbf{C}$ & $\eta_{\text {ES, }} \%$ \\
\hline \multirow{6}{*}{ 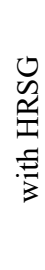 } & 1 & 197.8 & 20.14 \\
\hline & 2 & 148.0 & 20.51 \\
\hline & 3 & 94.2 & 21.08 \\
\hline & 4 & 95.9 & 21.13 \\
\hline & 5 & 96.3 & 21.39 \\
\hline & 6 & 97.2 & 21.36 \\
\hline \multicolumn{2}{|c|}{ without HRSG } & 522.9 & 14.18 \\
\hline
\end{tabular}

\section{Summary and conclusions}

From the political and ecological point of view, the development of renewable sources will be promoted because it leads to a decrease in consumption of nonrenewable primary energy. Nevertheless, the greater is the share of wind energy in the power system, the greater are the losses of conventional power plants. There are complications related to the introduction of RES to the network. Due to the priority of including the RES in the network, it is necessary to discontinue the work of coalfired steam plants. Also, the price of electricity becomes crucial, for example when the production of electricity is much higher than the consumption there is a necessity of selling it at lower prices. The storage of surplus energy and its use during increased demand promotes a conscious use of resources and sustainable development. Therefore, energy storage technologies are possibly the most beneficial solution to this problem and these technologies should be developed.

Referring to the analyzed systems, the use of a heat recovery system from the exhaust gases behind the expander increases the efficiency of the systems under consideration. Still, the efficiency values for the above cases are quite low. They could not be an alternative to Power-to-Gas-to-Power systems using fuel cells. In practice, fuel cells achieve energy efficiency of $40-$ $60 \%$ [19] therefore the case defined as a reference assuming the use of fuel cell in combination with electrolyser achives total efficiency of energy storage of $22.8-34.2 \%$ [20]. The issue of improvement of analyzed cases in order to increase efficiency should be considered. However, the big advantage of the combined cycle over the fuel cells is that the operation of fuel cells requires high financial expenditures, while the proposed systems consist of available elements and constitute less expensive technology. Moreover, exhaust gases generated by analyzed systems consist mostly of $\mathrm{H}_{2} \mathrm{O}$ and $\mathrm{CO}_{2}$ (used in the electrolysis and methanation processes or stored), so it can be assumed that these systems are emission free. In these analyses, many simplifications were used, which probably still inflates the obtained values of efficiency of the systems.

\section{Acknowledgement}

The scientific work is funded by the National Science Centre within the framework of the research project no. 2017/27/B/ST8/02270.

\section{References}

1. European Council. 2030 climate \& energy framework, (2014). Available at: $<$ https://ec.europa.eu $>$

2. An IPCC Special Report on the impacts of global warming of $1.5^{\circ} \mathrm{C}$ above pre-industrial levels and related global greenhouse gas emission pathways, in the context of strengthening the global response to the threat of climate change, sustainable development, and efforts to eradicate poverty. 2018 Intergovernmental Panel on Climate Change.

3. Transforming our world: the 2030 Agenda for Sustainable Development. United Nations A/RES/70/1 General Assembly.

4. Directive 2012/27/EU of the European Parliament and of the Council of 25 October 2012 on energy efficiency, amending Directives 2009/125/EC and 2010/30/EU and repealing Directives 2004/8/EC and 2006/32/EC, Official Journal of the European Union L315/1, (2012).

5. Communication from the commission to the European Parliament, the council, the European economic and social committee and the committee of the regions. Energy 2020, A strategy for competitive, sustainable and secure energy.

6. The European Wind Initiative Wind Power Research and Development to 2020. Available at: $<$ http://www.ewea.org $>$

7. Ibrahim H., Ilinca A., Perron J., Energy storage systems: Characteristics and comparisons, Renewable and Sustainable Energy Reviews, Vol. 5, pp.1221-1250, (2008).

8. Götz M., Lefebvre J., Mors F., McDaniel Koch A., Graf F., Bajohr S., Reimert R.,. Kolb T, Renewable Power-to-Gas: A technological and economic review, Renewable Energy, Vol. 85, pp.1371-1390, (2016).

9. Jentscha M., Trosta T., Sternerb M., Optimal Use of Power-to-Gas Energy Storage Systems in an $85 \%$ Renewable Energy Scenario, Energy Procedia, Vol. 46, pp. 254-261, (2014).

10. Lehner M., Tichler R., Steinmüller H., Koppe M., Power-to-Gas: Technology and Business Models. SpringerBriefs in Energy, (2014).

11. Benjaminsson G., Benjaminsson J., Rudberg R.B., Power to Gas - a Technical Review, Swedish Gas Technology Centre Rapport, (2013).

12. Ghaib K., Ben-Fares F.-Z., Power-to-methane: A state-of-the-art review, Renewable and Sustainable Energy Reviews, Vol. 81, pp. 433-446, (2018).

13. Ghaib K., Nitz K., Ben-Fares F.-Z., Chemical methanation of $\mathrm{CO}_{2}$ : A review, ChemBioEng Reviews, Vol. 3, pp. 266-275, (2016).

14. Iskov H., Rasmussen N.B., Global screening of projects and technologies for Power-to-Gas and BioSNG, Hørsholm, Denmark, Danish Gas Technology Centre, 2013, ISBN : 978-87-7795-373-6.

15. Gahleitner G., Hydrogen from renewable electricity: an international review of Power-to-Gas pilot plants 
for stationary applications, International Journal of Hydrogen Energy, Vol. 38, pp. 2039-2061, (2013).

16. Su X., Xu J., Liang B., Duan H., Hou B., Huang Y., Catalytic carbon dioxide hydrogenation to methane: A review of recent studies, Journal of Energy Chemistry, Vol. 25, pp. 553-565, (2016).

17. Kopyscinski J., Schildhauer T. J., Biollaz S. M., Production of synthetic natural gas (SNG) from coal and dry biomass - a technology review from 1950 to 2009, Fuel, Vol. 89, pp. 1763-1783, (2010).

18. Rönsch S., Schneider J., Matthischke S., Schlüter M., Götz M., Lefebvre J., Praseeth P., Bajohr S., Review on methanation - From fundamentals to current projects, Fuel, Vol. 166, pp. 276-296, (2016).

19. Edwards P.P., Kuznetsov V.L., David W.I.F., Brandon N.P., Hydrogen and fuel cells: Towards a sustainable energy future, Energy Policy, Vol. 36, pp. 4356-4362, (2008).

20. Bartela Ł., Katla D., Skorek-Osikowska A., Evaluation of conceptual energy storage systems based on the electrolysis process using gas expanders. Proceedings of the 32nd International Conference on Efficiency, Cost, Optimization, Simulation and Environmental Impact of Energy Systems. ECOS 2019, Wrocław, Poland, 23-28 June 2019, Ed. by Wojciech Stanek, Paweł Gładysz, Sebastian Werle, Wojciech Adamczyk. Gliwice: Institute of Thermal Technology, Silesian University of Technology, 2019, pp. 3523-3534, ISBN: 978-83-61506-51-5. 